\title{
Tahap pengetahuan isi kandungan tatabahasa Tamil Punarriyal dalam kalangan guru pelatih
}

\author{
Levels of grammartical content knowledge punarriyal among trainee teachers
}

\author{
Bavani Arumugam @ Seiyalu ${ }^{1,2}$, Abdul Jalil Othman², Mohana Dass Ramasamy ${ }^{3}$ \\ ${ }^{1}$ Jabatan Bahasa Moden, Fakulti Bahasa dan Komunikasi, \\ Universiti Pendidikan Sultan Idris, Tanjong Malim, Perak, Malaysia \\ ${ }^{2}$ Jabatan Bahasa dan Literasi, Fakulti Pendidikan, \\ Universiti Malaya, Kuala Lumpur, Malaysia \\ ${ }^{3}$ Jabatan Pengajian India, Fakulti Sastera dan Sains Sosial, \\ Universiti Malaya, Kuala Lumpur, Malaysia \\ *e-mail: bavani_um@siswa.um.edu.my
}

DOI: https://doi.org/10.37134/ejoss.vol5.1.7.2019

\begin{abstract}
This study examines the level of grammar content knowledge on punarriyal of Tamil grammar among the trainee teachers. This study is a survey using quantitative approach. A total of 92 Tamil language ISMP trainee teachers at one of the local universities were selected through a purposive sampling. Questionnaire was used as an instrument in this study. The questionnaire consists of 2 sections, part A and B. Part A is about the background of the sample, part B covers the Form Four Tamil grammar content knowledge. The data obtained were analysed using SPSS (Statistic Packages for Social Science) version 22.0. The findings show that, the study found the level of knowledge of Tamil grammar content at a moderately low level. The implication in the study found that the Tamil Language curriculum in the Ministry of Education Malaysia (KPM) had to formulate syllabus and syllabus description with emphasis on the importance of the Tamil grammar of punarriyal. Besides that, the trainee teachers and experienced teachers will also realize the importance of Tamil grammatical acquiring content knowledge.
\end{abstract}

Keywords: Content Knowledge, Trainee Teacher, Grammar of punarriyal

\begin{abstract}
Abstrak
Kajian ini bertujuan untuk mengenal pasti tahap pengetahuan isi kandungan tatabahasa punarriyal dalam kalangan guru pelatih. Kajian ini menggunakan pendekatan kuantitatif secara tinjauan. Kajian ini melibatkan 92 orang guru pelatih sebagai responden kajian daripada IPTA yang terpilih. Soal selidik ini terdiri daripada 2 bahagian iaitu bahagian A, dan B. Bahagian A adalah mengenai latar belakang sampel kajian, bahagian B merangkumi tentang pengetahuan isi kandungan tatabahasa Tamil Tingkatan Empat. Data-data yang diperoleh dianalisis dengan menggunakan perisian SPSS (Statistic Packages for Social Science) versi 22.0. Kajian mendapati tahap pengetahuan isi kandungan tatabahasa Tamil pada tahap yang sederhana rendah $(\mathrm{M}=2.805, \mathrm{SD}=0.403)$. Implikasi yang diperoleh menerusi kajian ini ialah Kementerian Pelajaran Malaysia (KPM) dicadangkan meneliti semula Sukatan Pelajaran dan Huraian Sukatan Pelajaran Bahasa Tamil dengan menitikberatkan kepentingan aspek tatabahasa Tamil, iaitu punarriyal. Kesan daripada ini, guru pelatih dan guru yang mengajar Bahasa Tamil akan dapat menyedari kepentingan penguasaan isi kandungan tatabahasa Tamil.
\end{abstract}

Kata kunci: Pengetahuan Isi Kandungan, Guru Pelatih, Tatabahasa punarriyal

\section{PENGENALAN}

Pengetahuan isi kandungan yang dikenali sebagai subject matter knowledge atau content knowledge dikaji secara luas kerana pengetahuan tersebut dianggap salah satu aspek yang harus dititikberatkan dalam latihan perguruan (Eggen \& Kauchak, 2007; Keser et al, 2010; Noor Shah Saad, 2006). Menurut Shulman (1986), pengetahuan guru dapat dikategorikan kepada tiga, iaitu pengetahuan isi kandungan, 
pengetahuan pedagogi isi kandungan dan pengetahuan kurikulum. Antara jenis-jenis pengetahuan tersebut, pengetahuan isi kandungan menonjol sebagai aspek penting untuk pendidikan guru (AslanTutak \& Adam, 2015). Guru yang kurang memberi perhatian terhadap pengetahuan isi kandungan sesuatu mata pelajaran merupakan satu punca kehilangan paradigma dalam bidang pendidikan (Shulman, 1986). Sehubungan itu, pengetahuan isi kandungan merupakan salah satu kefahaman yang mendalam tentang isi kandungan mata pelajaran yang akan diajar dengan menepati spesifikasi kurikulum atau sukatan pelajaran (Abdul Shatar, 2007; Ball \& Mcdiarmind, 1990, Borko \& Putnam, 1996; Cochran, King \& DeRuiter, 1993; Hlas \& Hildebrandf, 2010; Shulman, 1987).

\section{LATAR BELAKANG KAJIAN}

Pembentukan modal insan yang berkualiti semasa proses pengajaran di bilik darjah memerlukan kesungguhan dan dedikasi guru yang berilmu pengetahuan (Shing, Saat \& Loke, 2015). Pengetahuan bukan sahaja ditentukan berdasarkan kelayakan akademik seseorang guru tetapi sebenarnya lebih merujuk kepada kefahaman (understanding) pengetahuan isi kandungan yang menentukan keberkesanan pengajaran dan pembelajaran. Tanpa pengetahuan yang mendalam seorang guru tidak dapat mengendalikan pelajaran secara efektif (Alfaro, Kupczynski \& Mundy, 2015).

Sehubungan itu, kekurangan pengetahuan isi kandungan mewujudkan masalah pengajaran dalam bidang pendidikan (Oleg, Kim, Ward, Curtner, \& Li, 2016). Chee at.al, (2017) menyatakan kekurangan kefahaman isi kandungan dalam kalangan guru memberi kesan terhadap penerangan atau kemahiran yang tidak jelas serta menjejaskan komunikasi efektif dalam kalangan mereka. Pernyataan ini turut di sokong oleh kajian Chee at.al (2017) yang menunjukkan tahap penguasaan yang rendah dalam pengetahuan isi kandungan menyebabkan guru tidak berupaya untuk memberikan penerangan yang tepat tentang pembelajaran dan kemahiran yang diajar. Hal ini mengakibatkan, guru gagal menjawab soalan yang dikemukan oleh murid tentang pembelajaran dan kemahiran yang diajarnya. Oleh hal yang demikian, penguasaan pengetahuan isi kandungan harus diutamakan dalam kalangan pendidik. Kenyataan ini turut disokong oleh Coe et al. (2014) menjelaskan bahawa pengetahuan isi kandungan merupakan salah satu aspek yang penting di antara beberapa ciri-ciri amalan bilik darjah yang berkesan. Namun, beliau menegaskan bahawa,

\footnotetext{
"The most effective teachers have deep knowledge of the subjects they teach, and when teachers' knowledge falls below a certain level it is a significant impediment to students' learning" (Coe et al., 2014, ms.2).
}

Perkara yang sama dinyatakan Shulman (1986) bahawa aspek utama yang menentukan kefahaman murid terhadap sesuatu mata pelajaran adalah pengetahuan isi kandungan. Oleh hal yang demikian, seorang guru perlu melengkapkan diri dengan pengetahuan isi kandungan supaya guru tersebut dapat mengamalkan pengajaran dan pembelajaran secara efektif dalam bilik darjah (Iserbyt, Ward, \& Martens, 2015).

\section{PERNYATAAN MASALAH}

Pengajaran bergantung kepada pengetahuan guru di mana mereka harus mempunyai pengetahuan yang luas dalam bidang pendidikan (Metz, 2018; Iserbyt, Ward, \& Martens, 2015). Pengetahuan menjadi panduan kepada guru untuk mengambil keputusan khususnya semasa sesi pengajaran dan pembelajaran (Mitton Kukner \& Murray Orr, 2015). Isu kekurangan dan kelemahan pengetahuan isi kandungan dalam kalangan guru menunjukkan mereka tidak mempunyai persediaan yang sewajarnya untuk memulakan tugas sebagai seorang pendidik $(\mathrm{Xu}, 2015)$. Tambah membimbangkan lagi, kekurangan tersebut membataskan pengajaran guru dan mereka kurang berupaya bagi menggalakkan pemikiran kreatif dan inovatif serta kritis dalam pemikiran murid (Diezmann \& Watters, 2015).

Dalam konteks mata pelajaran Bahasa Tamil, Laporan Jemaah Nazir dan Jaminan Kualiti (2014) menjelaskan bahawa terdapat pengetahuan kandungan guru bahasa Tamil sekolah menengah masih berada pada tahap rendah, iaitu pemahaman isi kandungan Sukatan Pelajaran dan Huraian Sukatan 
Pelajaran terutama dalam aspek tatabahasa (Kementerian Pendidikan Malaysia 2014). Selain itu, Laporan Kupasan Mutu Jawapan Sijil Pelajaran Malaysia (SPM) tahun 2017 daripada KPM pula menunjukkan murid tidak mempunyai penguasaan yang mendalami dalam tatabahasa Tamil. Dalam konteks ini, murid kurang mahir dalam pengetahuan tatabahasa komponen punarriyal. Dengan ini, guru perlu memiliki tahap penguasaan tatabahasa yang agak tinggi serta memberi penerangan yang jelas kepada murid tanpa merumitkannya (Kementerian Pendidikan Malaysia, 2017).

Namun begitu, hasil kajian Manonmani Devi, Ani Omar dan Veeralaksmi (2017) menunjukkan kekurangan pengetahuan isi kandungan tatabahasa mata pelajaran bahasa Tamil menyebabkan ramai guru pelatih melakukan kesalahan tatabahasa dalam pengajaran. Dalam hal ini, guru pelatih tidak memberi tumpuan kepada hukum tatabahasa Tamil kerana komponen tersebut tidak diajar secara asing sebaliknya diselitkan dalam kemahiran bahasa yang lain iaitu mendengar, bertutur, membaca dan menulis di peringkat sekolah menengah. Beliau juga membuktikan bahawa guru pelatih bahasa Tamil kurang peka terhadap hukum tatabahasa terutama dari aspek punarriyal. Berdasarkan kepada permasalahan yang dibincangkan di atas, kajian ini dilaksanakan untuk mengenal pasti tahap pengetahuan isi kandungan tatabahasa punarriyal dalam kalangan guru pelatih.

\section{SOROTAN LITERATUR}

Warga pendidik yang profesional seharusnya mengetahui dan memiliki beberapa kriteria seperti menguasai isi kandungan mata pelajaran dan kurikulum yang disampaikan di dalam dan luar bilik darjah (Shulman, 1987). Malah, mereka juga perlu mahir mengenal pasti sikap, bakat dan kebolehan yang pelbagai dalam kalangan pelajar. Sehubungan itu, golongan pendidik harus memahami dengan teliti falsafah, objektif, nilai dan dasar pendidikan sesebuah negara. Kebanyakan penyelidik percayai bahawa pengetahuan isi kandungan memainkan peranan penting dalam keberkesanan pengajaran guru (Siping, 2013).

Kajian Oleg, Kim, Ward, Curtner, dan Li (2016) mendapati guru yang mempunyai pengetahuan isi kandungan yang baik boleh menghasilkan pengajaraan dan pembelajaran yang efektif. Pada masa yang sama, kajian mereka juga menjelaskan bahawa kehadiran ke bengkel dan kursus dapat membantu untuk meningkatkan pengetahuan seseorang guru itu sendiri. Kajian yang dilaksanakan oleh Rohaida Mazlan, (2017) juga menjelaskan perkara yang sama, iaitu menghadiri kursus latihan dalaman dan luaran, membaca sumber rujukan, mengakses sumber berasaskan web dan bekerja dengan rakan sekerja dapat membantu guru-guru untuk menguasai pengetahuan isi kandungan dalam sesuatu mata pelajaran. Begitu juga dengan kajian Donna dan Hick (2017) yang menunjukkan bahawa bahan kurikulum dapat membantu guru terutamanya guru pelatih untuk memperoleh maklumat yang banyak dan mengukuhkan pengetahuan isi kandungan mereka.

Selain itu, kajian Eric Rui Yuan (2016) menjelaskan bahawa bantuan guru-guru berpengalaman adalah sangat penting bagi guru pelatih untuk meningkatkan pengetahuan kandungan mereka. Turut menjelaskan guru berpengalaman harus dijadikan mentor oleh guru pelatih supaya mereka memperoleh bimbingan yang baik demi mempertingkatkan pengetahuan isi kandungan mereka secara menyeluruh. Memandangkan guru-guru pelatih kurang berpeluang untuk menghadiri bengkel dan kursus latihan seperti guru-guru biasa, tahap pengetahuan isi kandungan adalah masih rendah dalam kalangan guru pelatih (Herold \& Waring, 2017). Kajian yang dilaksanakan oleh Herold dan Waring (2017) menunjukkan bahawa pengetahuan isi kandungan telah memberi impak yang besar kepada guru pelatih. Demikian kerana, kekurangan pengetahuan isi kandungan telah menjejaskan keyakinan guru pelatih serta memberi kesan terhadap kaedah pengajaran guru pelatih di dalam bilik darjah. Kontradiksinya, dapat menggunakan teknik lebih kreatif dan efektif dalam pengajaran dengan lebih yakin. Maka, tidak dapat dinafikan bahawa pengetahuan isi kandungan merupakan unsur yang sangat penting yang harus dikuasai oleh seorang guru pelatih dengan baik.

Kesedaran yang tinggi terhadap pengetahuan isi kandungan tatabahasa (grammatical content knowledge) juga merupakan perkara yang penting dalam melaksanakan pengajaran bahasa secara berkesan (Myhill et.al, 2013). Namun, terdapat isu kekurangan dan kelemahan dalam pengetahuan isi kandungan tatabahasa (grammatical content knowledge). Alderson dan Horak (2011), Alderson, Clapham dan Steel (1997) dan Bloor (1986) telah menjalankan kajian untuk meneroka pengetahuan isi 
kandungan tatabahasa di peringkat universiti, terutamanya dalam kalangan guru pelatih. Dapatan kajian mereka menunjukkan bahawa pelajar pengajian Ijazah Bahasa Inggeris mempunyai pengetahuan tatabahasa yang terhad khususnya dari segi terminologi atau istilah tatabahasa. Pengajaran tatabahasa yang berkesan hanya berlaku apabila seseorang guru memiliki pengetahuan isi kandungan yang luas. Justeru itu, pengetahuan isi kandungan juga amat penting bagi seseorang guru tatabahasa. Kajian yang dijalankan oleh National Capital Language Resource Center, NCLRC, 2005 - 2015 juga membuktikan bahawa tatabahasa merupakan satu aspek utama dalam proses pembelajaran dan pemudahcaraan. Borg (2001) juga menegaskan bahawa kekurangan pengetahuan isi kandungan tatabahasa dalam kalangan guru akan mempengaruhi gaya pengajaran. Tambahan pula, kelemahan dalam pengetahuan isi kandungan tatabahasa menyebabkan guru pelatih lebih yakin mengajar pada peringkat teks sahaja, malah kurang yakin dari segi hukum-hukum tatabahasa (Andrews, 1994; Cajkler dan Hislam, 2002; Williamson dan Hardman, 1995 dan Wray, 1993).

Dalam konteks Bahasa Tamil pula, dapatan kajian Manonmani Devi (2015) membuktikan bahawa penguasaan aspek punar amat penting dalam penggunaan penulisan karya Tamil. Di samping itu, penguasaan tatabahasa punarriyal membantu bahasa Tamil untuk terus mengekalkan ketulenannya tanpa dipengaruhi oleh cara penulisan budaya bahasa asing. Kajian Manonmani, (2017) juga menjelaskan bahawa persepsi turut mempengaruhi pengetahuan isi kandungan tatabahasa seseorang guru. Beliau juga menyatakan bahawa persepsi guru tentang P\&P memainkan peranan yang penting dalam menentukan bagaimana guru tersebut melaksanakan pengajarannya di dalam bilik darjah. Ekoran daripada itu, guru mata pelajaran Bahasa Tamil mengajar dan menjelaskan bentuk-bentuk hukum tatabahasa sehingga membosankan murid (Manonmani Devi, 2015). Hal ini menjadikan pengajaran tatabahasa Tamil yang dijalankan dalam bilik darjah selalunya kurang menarik perhatian murid. Rumusan daripada kajian lampau, mendapati pengetahuan isi kandungan adalah sangat penting untuk dikuasai oleh seseorang guru bagi melaksanakan proses pembelajaran dan pemudahcaraan secara berkesan. Ia juga bersesuaian kepada seseorang guru bahasa terutamanya semasa mengajar aspek tatabahasa. Seorang guru khususnya guru pelatih harus berusaha untuk menguasai pengetahuan isi kandungan dengan sepenuhnya bagi menjamin pelaksanaan proses pembelajaran dan pemudahcaraan yang berkesan.

\section{METODOLOGI KAJIAN}

Kajian ini merupakan kajian kuantitatif secara tinjauan melalui soal selidik dengan tujuan untuk mengenal pasti secara menyeluruh tahap pengetahuan isi kandungan tatabahasa punarriyal dalam kalangan guru pelatih. Dalam kajian ini, populasi melibatkan guru pelatih program Bahasa Tamil Ijazah Sarjana Muda di salah sebuah universiti tempatan iaitu seramai 124. Guru pelatih bahasa Tamil yang dipilih dalam kajian ini terdiri daripada guru pelatih yang akan mengajar mata pelajaran bahasa Tamil di peringkat sekolah menengah. Sehubungan itu, dalam kajian ini, pengkaji menentukan saiz sampel kajian dengan mengikut pengiraan Krejcie dan Morgan (1970) yang telah menyenaraikan saiz sampel yang padat dengan saiz populasi kajian. Mengikut jadual penentuan saiz sampel oleh Krejcie dan Morgan (1970), jika terdapat sebanyak 124 populasi kajian, maka bilangan pemilihan sampel kajian yang sesuai ialah sebanyak 92. Dengan itu, pengkaji memilih seramai 92 sampel daripada populasi kajian secara sampel rawak mudah. Hal ini kerana pengkaji memberi peluang yang sama kepada setiap subjek dalam populasi kajian.

Instrumen yang digunakan bersesuaian dengan kaedah dan prosedur kajian. Kajian ini merupakan kajian kuantitatif yang menggunakan soal selidik sebagai alat utama bagi proses pengumpulan data. Instrumen kajian yang digunakan dalam kajian ini ialah soal selidik yang dibina sendiri oleh pengkaji bersesuaian dengan persetujuan pakar-pakar bidang yang berkaitan. Borang soal selidik yang dibina mengandungi dua bahagian iaitu Bahagian A untuk mengetahui latar belakang demografi responden, Bahagian B tentang tahap pengetahuan isi kandungan guru terhadap tatabahasa Tamil Tingkatan Empat. Bilangan item yang terdapat dalam soal selidik adalah seperti jadual 1 yang berikut: 
Jadual 1: Item Soal Selidik

\begin{tabular}{clc}
\hline Bahagian & \multicolumn{1}{c}{ Aspek } & Bilangan Item \\
\hline A & Latar Belakang Demografi & 7 \\
B & $\begin{array}{l}\text { Tahap Pengetahuan isi kandungan } \\
\text { terhadap Tatabahasa Tamil }\end{array}$ & 24 \\
\hline
\end{tabular}

Setiap item bagi Bahagian B instrumen tersebut mempunyai lima pilihan jawapan iaitu menggunakan skala Likert lima tahap $1=$ Sangat tidak setuju, $2=$ Tidak setuju, $3=$ Tidak pasti, $4=$ Setuju dan $5=$ Sangat setuju. Setelah menjalankan kajian rintis, nilai Alpha Cronbach yang diperoleh ialah 0.954. Hal ini bermakna item soal selidik ini mempunyai tahap kebolehpercayaan yang tinggi. Oleh hal yang demikian, soal selidik ini sesuai untuk diguna pakai bagi menjalankan kajian sebenar.

Data soal selidik untuk kajian ini diproses dengan menggunakan 'Statistical Package for the Sosial Science' versi 22.0 (SPSS) dengan menggunakan analisis deskriptif. Statistik seperti kekerapan, peratus, min dan sisihan piawai digunakan dalam analisis deskriptif. Analisis deskriptif digunakan dalam kajian ini untuk menjelaskan tahap pengetahuan isi kandungan tatabahasa punarriyal Tingkatan empat dalam kalangan guru pelatih. Bagi menjawab persoalan tersebut pengkaji menggunakan interpretasi skor min (Nunnally, 1967) seperti dalam jadual 2 yang berikut.

Jadual 2: Interpretasi Skor Min Nunnally (1967)

\begin{tabular}{cl}
\hline Skor Min & Interpretasi Skor Min \\
\hline $1.00-2.00$ & Rendah (R) \\
$2.01-3.00$ & Sederhana Rendah (SR) \\
$3.01-4.00$ & Sederhana Tinggi (ST) \\
$4.01-5.00$ & Tinggi (T) \\
\hline
\end{tabular}

\section{DAPATAN KAJIAN}

Bahagian ini adalah untuk menjawab objektif kajian melalui tinjauan soal selidik yang melibatkan 92 orang guru latih sebagai responden kajian daripada IPTA yang terpilih. Data menganalisis secara analisis deskriptif dengan menggunakan kekerapan, peratus, min dan sisihan piawai.

\section{Latar Belakang Responden Kajian}

Bahagian ini melaporkan data demografi responden kajian seperti jantina, umur, kelulusan akademik, pencapaian tertinggi dalam mata pelajaran bahasa Tamil, pengkhususan Bahasa Tamil di peringkat universiti dan kursus yang pernah menghadiri berkaitan dengan tatabahasa Tamil seperti jadual di bawah berikut :

Jadual 3: Demografi responden yang terlibat dalam kajian

\begin{tabular}{cccc}
\hline Demografi & Deskripsi & Kekerapan & Peratus \\
\hline Jantina & Lelaki & 20 & 21.7 \\
& Perempuan & 72 & 78.3 \\
\hline Umur & 20 Tahun & 29 & 31.5 \\
& 21 Tahun & 31 & 33.7 \\
& 22 Tahun & 17 & 18.5 \\
& 23 Tahun & 14 & 15.2 \\
& >23 Tahun & 1 & 1.1 \\
\hline
\end{tabular}




\begin{tabular}{cccc}
\hline Kelulusan akademik & SPM & 0 & 0 \\
& STPM & 92 & 100 \\
\hline Pencapaian tertinggi & SPM & 50 & 54.3 \\
dalam mata pelajaran & STPM & 42 & 45.7 \\
Bahasa Tamil & & 92 & 100 \\
\hline Pengkhususan Mata & Bahasa Tamil & 32 & 34.8 \\
pelajaran & Kesusasteraan Tamil & 3 & 3.3 \\
(Major) & Ekonomi & 4 & 4.3 \\
(Minor) & Prinsip Akaun & 5 & 5.4 \\
& Geografi & 4 & 4.3 \\
& Informasi Teknologi & 5 & 5.4 \\
& Sejarah & 39 & 42.4 \\
\hline Kursus-kursus yang & Tiada & 25 & 35.9 \\
telah menghadiri & Bengkel Tholkaapiyam & 20 & 21.7 \\
berkaitan dengan & Ceramah Bahasa & 47 & 51 \\
tatabahasa Tamil & Tamil & - & - \\
& Tidak pernah & - & - \\
\hline
\end{tabular}

Jadual 3 menunjukkan dapatan daripada analisis demografi responden yang terlibat dalam kajian ini. Berdasarkan jadual tersebut, responden yang terlibat adalah terdiri daripada 72 orang perempuan dan 20 orang lelaki. Responden yang berumur 21 tahun dengan bilangan sebanyak 31 orang iaitu merangkumi 33.7\%, lebih ramai berbanding dengan responden yang berumur 23 tahun ke atas sebanyak $1.1 \%$ sahaja. Kelulusan akademik responden dalam kajian ini menunjukkan kesemua responden mempunyai kelulusan STPM iaitu 100\%. Pencapaian tertinggi mata pelajaran Bahasa Tamil responden dalam kajian ini dalam SPM sebanyak 50 orang responden iaitu $54.3 \%$ berbanding dengan STPM hanya 42 orang responden dengan $45.7 \%$. Ini menunjukkan lebih daripada separuh responden mempunyai pencapaian tinggi Bahasa Tamil dalam SPM. Pengkhususan Mata Pelajaran pula menunjukkan kesemua responden iaitu 92 orang guru pelatih IPTA mengambil mata pelajaran Bahasa Tamil sebagai subjek major (100\%). Malah, terdapat beberapa subjek yang telah dipilih sebagai subjek minor seperti Kesusasteraan Tamil (34.8 \%), Ekonomi (3.3 \%), Prinsip Akaun (4.3), Geografi (5.4\%), Informasi Teknologi (4.3\%), Sejarah (5.4\%) dan sebanyak 42.4\% tidak mengambil subjek minor kerana mereka adalah pelajar yang berada dalam semester pertama. Bagi item terakhir iaitu kursus yang pernah dihadiri oleh guru pelatih pula menunjukkan bahawa lebih dari separuh guru pelatih iaitu 63.0 peratus tidak pernah menghadiri sebarang kursus. Manakala, yang selebihnya pernah menghadiri bengkel Tholkaapiyam (9.8\%) dan ceramah bahasa Tamil (16.3\%).

\section{Tahap Pengetahuan Isi Kandungan punarriyal dalam Tatabahasa Tamil Tingkatan Empat}

Jadual 5 (a): Taburan Kekerapan, Sisihan Piawai dan Interpretasi Min Tahap Pengetahuan Isi Kandungan punarriyal dalam Tatabahasa Tamil Tingkatan Empat

\begin{tabular}{|c|c|c|c|c|c|c|c|c|}
\hline \multirow[t]{2}{*}{ Pernyataan } & \multicolumn{5}{|c|}{$\begin{array}{c}\text { Tahap Persetujuan } \\
\text { (Kekerapan / Peratus) }\end{array}$} & \multirow[t]{2}{*}{$\begin{array}{l}\text { Min } \\
(\mathrm{M})\end{array}$} & \multirow[t]{2}{*}{$\begin{array}{c}\text { Sisihan } \\
\text { Piawai } \\
\text { (S.P) }\end{array}$} & \multirow[t]{2}{*}{ Tahap } \\
\hline & 1 & 2 & 3 & 4 & 5 & & & \\
\hline \multirow{2}{*}{$\begin{array}{l}\text { Saya memahami definisi } \\
\text { punarriyal dalam } \\
\text { tatabahasa Tamil. }\end{array}$} & 0 & 37 & 29 & 23 & 3 & \multirow[b]{2}{*}{2.913} & \multirow[b]{2}{*}{0.885} & \multirow[b]{2}{*}{ SR } \\
\hline & 0 & 40.2 & 31.5 & 25.0 & 3.3 & & & \\
\hline \multirow{2}{*}{$\begin{array}{l}\text { Saya boleh memahami } \\
\text { hukum-hukum punarriyal. }\end{array}$} & 0 & 42 & 38 & 12 & 0 & \multirow{2}{*}{2.674} & \multirow{2}{*}{0.697} & \multirow{2}{*}{ SR } \\
\hline & 0 & 45.7 & 41.3 & 13.0 & 0 & & & \\
\hline
\end{tabular}




\begin{tabular}{|c|c|c|c|c|c|c|c|c|}
\hline $\begin{array}{l}\text { Saya memahami hukum- } \\
\text { hukum tōnral. }\end{array}$ & 14.1 & 5.4 & 38.0 & 20.7 & $\begin{array}{c}20 \\
21.7\end{array}$ & 3.304 & 1.273 & ST \\
\hline $\begin{array}{l}\text { Saya boleh menyatakan } \\
\text { hukum tōnral dengan } \\
\text { memberikan contoh yang } \\
\text { sesuai. }\end{array}$ & 0 & 40.2 & 31.5 & 23 & 3 & 2.913 & 0.885 & SR \\
\hline $\begin{array}{l}\text { Saya boleh menyatakan } \\
\text { hukum mai îrrup } \\
\text { panpupeyarp punarcci } \\
\text { dengan betul. }\end{array}$ & 5.4 & 40.2 & 41.3 & 13.0 & $\begin{array}{l}0 \\
0\end{array}$ & 2.620 & 0.782 & SR \\
\hline $\begin{array}{l}\text { Saya boleh menyatakan } \\
\text { contoh-contoh yang sesuai } \\
\text { bagi mai } \overline{\underline{t}} \underline{\text { rqup }} \\
\text { panpupeyarp punarcci } \\
\text { berdasarkan hukum- } \\
\text { hukum. }\end{array}$ & 20.7 & 60.9 & 18.5 & 0 & $\begin{array}{l}0 \\
0\end{array}$ & 1.978 & 0.629 & SR \\
\hline
\end{tabular}

Jadual 5 (a) menunjukkan bahawa tahap pengetahuan isi kandungan punarriyal dalam tatabahasa Tamil Tingkatan Empat. Item yang mencapai tahap sederhana tinggi ialah item yang menyatakan bahawa responden memahami hukum-hukum tōnral. Item ini mencapai $\min (\mathrm{M}=3.304, \mathrm{~S} . \mathrm{P}=1.273)$. Item-item lain hanya mencapai tahap sederhana rendah. Item pertama "Saya memahami definisi punarriyal dalam tatabahasa Tamil" dan item keempat "Saya boleh menyatakan hukum tōnral dengan memberikan contoh yang sesuai" telah mencapai $(\mathrm{M}=2.913, \mathrm{~S} . \mathrm{P}=0.885)$. Item yang mencapai min paling rendah ialah "Saya boleh menyatakan contoh-contoh yang sesuai bagi mai îtrup panpupeyarp punarcci berdasarkan hukum-hukum".

\section{Tahap Pengetahuan Isi Kandungan valimikum ițanka! dalam Tatabahasa Tamil Tingkatan Empat}

Jadual 5 (b): Taburan Kekerapan, Sisihan Piawai dan Interpretasi Min Tahap Pengetahuan Isi Kandungan valimikum itankkal dalam Tatabahasa Tamil Tingkatan Empat

\begin{tabular}{|c|c|c|c|c|c|c|c|c|}
\hline \multirow[t]{2}{*}{ Pernyataan } & \multicolumn{5}{|c|}{$\begin{array}{c}\text { Tahap Persetujuan } \\
\text { (Kekerapan / Peratus) }\end{array}$} & \multirow[t]{2}{*}{$\begin{array}{l}\text { Min } \\
(\mathrm{M})\end{array}$} & \multirow{2}{*}{$\begin{array}{c}\text { Sisihan } \\
\text { Piawai } \\
\text { (S.P) }\end{array}$} & \multirow[t]{2}{*}{ Tahap } \\
\hline & 1 & 2 & 3 & 4 & 5 & & & \\
\hline \multirow{2}{*}{$\begin{array}{l}\text { Saya memahami definisi } \\
\text { valimikum ițankal dalam } \\
\text { tatabahasa Tamil. }\end{array}$} & 16 & 33 & 40 & 3 & 0 & \multirow[b]{2}{*}{2.326} & \multirow[b]{2}{*}{0.780} & \multirow[b]{2}{*}{ SR } \\
\hline & 17.4 & 35.9 & 43.5 & 3.3 & 0 & & & \\
\hline \multirow{2}{*}{$\begin{array}{l}\text { Saya boleh menyatakan } \\
\text { hukum-hukum uvamaittokaiyil } \\
\text { valimikum berdasarkan } \\
\text { sukatan pelajaran Tingkatan } \\
\text { Empat. }\end{array}$} & 0 & 33 & 35 & 24 & 0 & \multirow[b]{2}{*}{2.902} & \multirow[b]{2}{*}{0.785} & \multirow[b]{2}{*}{ SR } \\
\hline & 0 & 35.9 & 38.0 & 26.1 & 0 & & & \\
\hline \multirow{2}{*}{$\begin{array}{l}\text { Saya boleh membezakan } \\
\text { hukum-hukum uvamaittokaiyil } \\
\text { valimikum dengan } \\
\text { memberikan contoh yang } \\
\text { sesuai. }\end{array}$} & 0 & 37 & 29 & 23 & 3 & \multirow{2}{*}{2.913} & \multirow{2}{*}{0.885} & \multirow{2}{*}{ SR } \\
\hline & 0 & 40.2 & 31.5 & 25.0 & 3.3 & & & \\
\hline \multirow{2}{*}{$\begin{array}{l}\text { Saya boleh menyatakan } \\
\text { hukum-hukum } \bar{a} r \bar{r} \bar{m} \\
\text { verrrumaittokaiyil valimikum } \\
\text { berdasarkan sukatan pelajaran } \\
\text { Tingkatan Empat. }\end{array}$} & 0 & 37 & 29 & 23 & 3 & \multirow{2}{*}{2.913} & \multirow{2}{*}{0.885} & \multirow{2}{*}{ SR } \\
\hline & 0 & 40.2 & 31.5 & 25.0 & 3.3 & & & \\
\hline
\end{tabular}




\begin{tabular}{|c|c|c|c|c|c|c|c|c|}
\hline $\begin{array}{l}\text { Saya boleh membezakan } \\
\text { hukum-hukum ārām } \\
\text { vērrumaittokaiyil valimikum } \\
\text { dengan memberikan contoh } \\
\text { yang sesuai. }\end{array}$ & 0 & $\begin{array}{c}41 \\
44.6\end{array}$ & 41.3 & $\begin{array}{c}13 \\
14.1\end{array}$ & 0 & 2.696 & 0.707 & SR \\
\hline $\begin{array}{l}\text { Saya boleh menyatakan } \\
\text { hukum-hukum } \bar{a} y, \text { poy eñ } \\
\text { muțiyum } \\
\text { vinaiyeccattirkuppiraku } \\
\text { valimikum berdasarkan } \\
\text { sukatan pelajaran Tingkatan } \\
\text { Empat. }\end{array}$ & 0 & 40.2 & 31.5 & 25.0 & 3.3 & 2.913 & 0.885 & SR \\
\hline $\begin{array}{l}\text { Saya boleh membezakan jenis- } \\
\text { jenis } \bar{a} \text { y, pōy enru mutiyum } \\
\text { vinaiyeccattikkuppiraku } \\
\text { valimikum dengan } \\
\text { memberikan contoh yang } \\
\text { sesuai. }\end{array}$ & 0 & $\begin{array}{c}37 \\
40.2\end{array}$ & $\begin{array}{c}29 \\
31.5\end{array}$ & $\begin{array}{c}23 \\
25.0\end{array}$ & $\begin{array}{c}3 \\
3.3\end{array}$ & 2.913 & 0.885 & SR \\
\hline $\begin{array}{l}\text { Saya boleh menyatakan jenis- } \\
\text { jenis tanik kurréluttai } \\
\text { atuttuvarum ākärattinpin } \underline{n} \\
\text { valimikum berdasarkan } \\
\text { sukatan pelajaran Tingkatan } \\
\text { Empat. }\end{array}$ & 0 & $\begin{array}{c}41 \\
44.6\end{array}$ & $\begin{array}{c}38 \\
41.3\end{array}$ & $\begin{array}{c}13 \\
14.1\end{array}$ & $\begin{array}{l}0 \\
0\end{array}$ & 2.696 & 0.707 & SR \\
\hline $\begin{array}{l}\text { Saya boleh membezakan jenis- } \\
\text { jenis tanik kurreluttai } \\
\text { atuttuvarum ākärattinping } \\
\text { valimikum dengan } \\
\text { memberikan contoh yang } \\
\text { sesuai. }\end{array}$ & 0 & 37 & 29 & 23 & 3.3 & 2.913 & 0.885 & SR \\
\hline $\begin{array}{l}\text { Nota: *1- Sangat Tidak Setuju, } 2 \text { - Tidak } \\
\text { Jadual } 5 \text { (b) menunjukkan item-ite } \\
\text { itankal. Kesemua item dalam ter } \\
\text { dalam tema ini ialah } 2.913 \text { dan s } \\
\text { boleh membezakan hukum-huk } \\
\text { sesuai", "Saya boleh menyatak } \\
\text { sukatan pelajaran Tingkatan Emp } \\
\text { vinaiyeccattirkuppiraku valimiku } \\
\text { membezakan jenis-jenis āy, pōye } \\
\text { contoh yang sesuai" dan "Say } \\
\text { âkărattinpin valimikum dengan m } \\
\text { paling rendah ialah "Saya memah } \\
\text { 2.326, S.P=0.780). }\end{array}$ & berd & $\begin{array}{l}\text { dak Past } \\
\text { aa kedu } \\
\text { fa men } \\
\text { vai } 0.8 \\
\text { ittokaiy } \\
\text { hukum } \\
\text { boleh } \\
\text { rkan su } \\
\text { m vina } \\
\text { membe } \\
\text { contoh } \\
\text { i valim }\end{array}$ & $\begin{array}{l}\text {, iaitu } \\
\text { capai ta } \\
\text { 5. Iten } \\
\text { il vali } \\
\bar{a} \underline{\text { rām }} \\
\text { menyat } \\
\text { katan } \\
\text { yeccatt } \\
\text { zakan } \\
\text { yang s } \\
\text { kum itc }\end{array}$ & $\begin{array}{l}\text { hap pe } \\
\text { hap sec } \\
\text {-item } \\
\text { itkum } \\
\text { vêrram } \\
\text { ken hu } \\
\text { elajara } \\
\text { rkuppin } \\
\text { enis-je } \\
\text { suai". }\end{array}$ & $\begin{array}{l}\text { denga } \\
\text { aittok } \\
\text { kum- } \\
\text { Tin }\end{array}$ & $\begin{array}{l}\text { Ian isi k } \\
\text { rendah. } \\
\text { encapai } \\
\text { memb } \\
\text { iyil val } \\
\text { ikum āy } \\
\text { katan E } \\
\text { imikum } \\
\text { ik kurr } \\
\text { la, item } \\
\text { abahasa }\end{array}$ & $\begin{array}{l}\text { dungan } \\
\text { Min yan } \\
\text { in ini ia } \\
\text { kan con } \\
\text { kum be } \\
\text { oyy enr } \\
\text { at", "S } \\
\text { ngan me } \\
\text { ettai at } \\
\text { ang men }\end{array}$ & $\begin{array}{l}\text { imiku } \\
\text { arting } \\
\text { "Sa } \\
\text { yai } \\
\text { asark. } \\
\text { utiyu } \\
\text { bol } \\
\text { berik. } \\
\text { uvaru } \\
\text { pai m }\end{array}$ \\
\hline
\end{tabular}

\section{Tahap Pengetahuan Isi Kandungan valimikä ițanka! dalam Tatabahasa Tamil Tingkatan Empat}

Jadual 5 (c): Taburan Kekerapan, Sisihan Piawai dan Interpretasi Min Tahap Pengetahuan Isi Kandungan valimikā ițankal dalam Tatabahasa Tamil Tingkatan Empat

$\begin{array}{cccc}\text { Pernyataan } & \text { Tahap Persetujuan } & \text { Min } & \text { Sisihan } \\ \text { (Kekerapan / Peratus) } & \text { (M) } & \text { Piawai } & \\ & & & \text { (S.P) }\end{array}$

$\begin{array}{lllll}1 & 2 & 3 & 4 & 5\end{array}$




\begin{tabular}{|c|c|c|c|c|c|c|c|c|}
\hline $\begin{array}{l}\text { Saya memahami definisi } \\
\text { valimika itankkal dalam } \\
\text { tatabahasa Tamil. }\end{array}$ & 0 & 35.9 & 38.0 & 26.1 & $\begin{array}{l}0 \\
0\end{array}$ & 2.902 & 0.785 & SR \\
\hline $\begin{array}{l}\text { Saya boleh menyatakan } \\
\text { hukum-hukum vilittoțaril } \\
\text { valimikātu berdasarkan } \\
\text { sukatan pelajaran Tingkatan } \\
\text { Empat. }\end{array}$ & 0 & 35.9 & 42.4 & 21.7 & 0 & 2.859 & 0.750 & SR \\
\hline $\begin{array}{l}\text { Saya boleh membezakan } \\
\text { hukum-hukum vilittoțaril } \\
\text { valimikātu dengan } \\
\text { memberikan contoh yang } \\
\text { sesuai. }\end{array}$ & 0 & 42.4 & 47.8 & 8.7 & $\begin{array}{c}1 \\
1.1\end{array}$ & 2.685 & 0.678 & SR \\
\hline $\begin{array}{l}\text { Saya boleh menyatakan } \\
\text { hukum-hukum } \\
\text { vinaittokaiyiñpin valimikātu } \\
\text { berdasarkan sukatan } \\
\text { pelajaran Tingkatan Empat. }\end{array}$ & 0 & $\begin{array}{c}31 \\
33.7\end{array}$ & $\begin{array}{c}35 \\
38.0\end{array}$ & $\begin{array}{c}26 \\
28.3\end{array}$ & $\begin{array}{l}0 \\
0\end{array}$ & 2.946 & 0.790 & SR \\
\hline $\begin{array}{l}\text { Saya boleh membezakan } \\
\text { hukum-hukum } \\
\text { vinaittokaiyiñpin valimikātu } \\
\text { dengan memberikan contoh } \\
\text { yang sesuai. }\end{array}$ & 0 & $\begin{array}{c}33 \\
35.0\end{array}$ & $\begin{array}{l}35 \\
38.0\end{array}$ & $\begin{array}{c}24 \\
26.1\end{array}$ & $\begin{array}{l}0 \\
0\end{array}$ & 2.902 & 0.785 & SR \\
\hline $\begin{array}{l}\text { Saya boleh menyatakan } \\
\text { hukum-hukum } \\
\text { peyareccattinpin valimikätu } \\
\text { berdasarkan sukatan } \\
\text { pelajaran Tingkatan Empat }\end{array}$ & 0 & $\begin{array}{c}37 \\
40.2\end{array}$ & $\begin{array}{c}29 \\
31.5\end{array}$ & $\begin{array}{c}23 \\
25.0\end{array}$ & $\begin{array}{c}3 \\
3.3\end{array}$ & 2.913 & 0.885 & SR \\
\hline $\begin{array}{l}\text { Saya boleh membezakan } \\
\text { hukum-hukum } \\
\text { peyareccattinpin valimikātu } \\
\text { dengan memberikan contoh } \\
\text { yang sesuai. }\end{array}$ & 0 & $\begin{array}{c}41 \\
44.6\end{array}$ & 38 & 13 & $\begin{array}{l}0 \\
0\end{array}$ & 2.696 & 0.707 & SR \\
\hline $\begin{array}{l}\text { Nota: *1- Sangat Tidak Setuju, } 2-\mathrm{Ti} \\
\text { Jadual } 5 \text { (c) menunjukkan taha } \\
\text { Tingkatan Empat. Berdasarkan } \\
\text { yang mencapai min tertinggi ia } \\
\text { berdasarkan sukatan pelajaran } \\
\text { min kedua tertinggi ialah " } \\
\text { berdasarkan sukatan pelajaran } \\
\text { "Saya memahami definisi வல } \\
\text { boleh membezakan hukum-h } \\
\text { sesuai" }(\mathrm{M}=2.902 \text {, S.P }=0.7 \\
\text { membezakan hukum-hukum } v \\
(\mathrm{M}=2.685, \mathrm{~S} . \mathrm{P}=0.678) .\end{array}$ & Бा இ & $\begin{array}{l}\text { an isi } \\
\text { s, kese } \\
\text { leh mer } \\
\text { npat" } \\
\text { menya } \\
\text { Empat" } \\
\text { sள் (va } \\
\text { okaiyin } \\
\text { la, iten } \\
\text { lit }\end{array}$ & $\begin{array}{l}\text { i, } 4-\mathrm{set} \\
\text { andung } \\
\text { nua ite } \\
\text { yatakar } \\
\text { engan ( } \\
\text { akan } \\
\text { dengan } \\
\text { imikā } i \\
\text { pin va }\end{array}$ & $\begin{array}{l}\text { an vali } \\
\text { n berad } \\
\text { hukum } \\
\mathrm{M}=2.9 \\
\text { ukum-1 } \\
(\mathrm{M}=2 \\
\text { añkal) } \\
\text { imikatu } \\
\text { mencap }\end{array}$ & $\begin{array}{l}\text { 13, } \\
\text { alam } \\
\text { deng }\end{array}$ & $\begin{array}{l}\dot{n} k a l \text { dal } \\
\text { ahap sec } \\
\text { vinaitto } \\
0.790 \text { ). } \\
\text { peyarecc } \\
\mathrm{P}=0.88 \\
\text { atabahas } \\
\text { a memb } \\
\text { terendal } \\
\text { contoh y }\end{array}$ & $\begin{array}{l}\text { tatabah } \\
\text { rhana ren } \\
\text { aiyinpinin } \\
\text { em yang } \\
\text { ttinpin } \\
\text {. Seterus } \\
\text { Tamil" } \\
\text { ikan cor } \\
\text { ialah "S } \\
\text { ng sesua }\end{array}$ & $\begin{array}{l}\text { Tam } \\
\text { h. Iter } \\
\text { imikāt } \\
\text { encap } \\
\text { imikāt } \\
\text { a, iter } \\
\text { "Say } \\
\text { h yan } \\
\text { a bole }\end{array}$ \\
\hline
\end{tabular}

Kaedah yang digunakan untuk menguasai isi kandungan Tatabahasa Tamil Tingkatan Empat

Jadual 5 (d): Taburan Kekerapan, Sisihan Piawai dan Interpretasi Min Kaedah yang digunakan untuk Menguasai Isi Kandungan Tatabahasa Tamil Tingkatan Empat

$\begin{array}{lcccc}\text { Pernyataan } & \text { Tahap Persetujuan } & \text { Min } & \text { Sisihan } & \text { Tahap } \\ & \text { (Kekerapan / Peratus) } & \text { (M) } & \text { Piawai } & \end{array}$




\begin{tabular}{|c|c|c|c|c|c|c|c|c|}
\hline & 1 & 2 & 3 & 4 & 5 & & \multirow{6}{*}{0.885} & \multirow{6}{*}{ SR } \\
\hline \multirow{5}{*}{$\begin{array}{l}\text { Saya menguasai isi } \\
\text { kandungan punarriyal } \\
\text { dalam sukatan pelajaran } \\
\text { Bahasa Tamil Tingkatan } \\
\text { Empat. }\end{array}$} & 0 & 37 & 29 & 23 & 3 & \multirow{5}{*}{2.913} & & \\
\hline & & & & & & & & \\
\hline & 0 & 40.2 & 31.5 & 25.0 & 3.3 & & & \\
\hline & & & & & & & & \\
\hline & & & & & & & & \\
\hline \multirow{5}{*}{$\begin{array}{l}\text { Saya tidak menghadapi } \\
\text { masalah untuk menguasai } \\
\text { isi kandungan punarriyal } \\
\text { dalam sukatan pelajaran } \\
\text { Bahasa Tamil Tingkatan } \\
\text { Empat. }\end{array}$} & 0 & 41 & 38 & 13 & 0 & \multirow{5}{*}{2.696} & \multirow{5}{*}{0.707} & \multirow{5}{*}{ SR } \\
\hline & & & & & & & & \\
\hline & 0 & 44.6 & 41.3 & 14.1 & 0 & & & \\
\hline & & & & & & & & \\
\hline & & & & & & & & \\
\hline Saya menguasai isi & 0 & 39 & 44 & 8 & 1 & \multirow{3}{*}{2.685} & \multirow{3}{*}{0.678} & \multirow{3}{*}{ SR } \\
\hline kandungan tatabahasa & & & & & & & & \\
\hline $\begin{array}{l}\text { Tamil dengan membaca } \\
\text { sumber rujukan. }\end{array}$ & 0 & 42.4 & 47.8 & 8.7 & 1.1 & & & \\
\hline Saya menguasai isi & 0 & 31 & 35 & 26 & 0 & \multirow{3}{*}{2.946} & \multirow{3}{*}{0.790} & \multirow{3}{*}{ SR } \\
\hline kandungan tatabahasa & & & & & & & & \\
\hline $\begin{array}{l}\text { Tamil dengan mengakses } \\
\text { bahan berasaskan internet. }\end{array}$ & 0 & 33.7 & 38.0 & 28.3 & 0 & & & \\
\hline Saya menguasai isi & 0 & 33 & 35 & 24 & 0 & \multirow{3}{*}{2.902} & \multirow{3}{*}{0.785} & \multirow{3}{*}{ SR } \\
\hline kandungan tatabahasa & & & & & & & & \\
\hline $\begin{array}{l}\text { Tamil dengan menghadiri } \\
\text { bengkel atau kursus yang } \\
\text { berkaitan. }\end{array}$ & 0 & 35.9 & 38.0 & 26.1 & 0 & & & \\
\hline Saya menguasai isi & 0 & 37 & 29 & 23 & 3 & \multirow{3}{*}{2.913} & \multirow{3}{*}{0.885} & \multirow{3}{*}{ SR } \\
\hline kandungan tatabahasa & & & & & & & & \\
\hline $\begin{array}{l}\text { Tamil dengan berkongsi } \\
\text { ilmu bersama rakan sekerja. }\end{array}$ & 0 & 40.2 & 31.5 & 25.0 & 3.3 & & & \\
\hline
\end{tabular}

Jadual 5 (d) menunjukkan kaedah yang digunakan untuk menguasai isi kandungan tatabahasa Tamil Tingkatan Empat. Kesemua item bagi tema ini juga berada pada tahap senderhana rendah. Item dengan min yang tertinggi ialah "Saya menguasai isi kandungan tatabahasa Tamil dengan mengakses bahan berasaskan internet" dengan $(\mathrm{M}=2.946, \mathrm{~S} . \mathrm{P}=0.790)$. Seterusnya, min kedua tertinggi, iaitu $(\mathrm{M}=2.913$, $\mathrm{S} . \mathrm{P}=0.885)$ dicapai oleh dua item iaitu "Saya menguasai isi kandungan punarriyal dalam sukatan pelajaran Bahasa Tamil Tingkatan Empat" dan "Saya menguasai isi kandungan tatabahasa Tamil dengan berkongsi ilmu bersama rakan sekerja". Item yang mendapat min terendah bagi tema ini ialah "Saya menguasai isi kandungan tatabahasa Tamil dengan membaca sumber rujukan" dengan ( $\mathrm{M}=$ 2.685, S.P=0.678).

\section{PERBINCANGAN}

Dapatan kajian ini mendapati tahap pengetahuan isi kandungan tatabahasa Tamil dalam kalangan guru pelatih berada pada tahap yang rendah dengan $(\mathrm{M}=2.805, \mathrm{SD}=0.403)$. Mengikut pernyataan Manonmani Devi dan Ani Omar (2019), guru kerap melakukan kesalahan tatabahasa kerana mereka tidak mempunyai tahap penguasaan tatabahasa Tamil yang cemerlang. Mereka kurang mahir dan tidak sentiasa peka terhadap hukum tatabahasa Tamil terutama dalam punarriyal. Tatabahasa punarriyal merupakan bahagian yang amat penting dan satu aspek yang unik serta istimewa dalam tatabahasa Tamil. Pendapat ini turut disokong oleh Munusamy (2011) yang berpendapat bahawa penguasaan pengetahuan bahasa seorang murid lebih bergantung kepada pengetahuan bahasa yang dimiliki oleh gurunya. Dengan kata lain, guru perlu menguasai sepenuhnya pengetahuan aspek tatabahasa dengan baik bagi membantu pencapaian murid. 
Pengetahuan isi kandungan yang rendah dalam kalangan guru akan menyebabkan keyakinan diri dalam kalangan guru merosot. Kajian mereka turut menjelaskan bahawa apabila keyakinan guru merosot, memberi kesan terhadap kaedah pengajaran guru. Dapatan kajian turut membuktikan Xu (2015) menyatakan kekurangan pengetahuan isi kandungan dalam kalangan guru menyebabkan mereka tidak mempunyai persediaan yang sewajarnya untuk memulakan tugas sebagai seorang pendidik. Lafayette (1993) menyatakan bahawa guru bahasa perlu menjadi "specialist component" (komponen pakar) dalam pendidikan bahasa misalnya mereka harus menguasai pengetahuan mengenai budaya, bahasa, linguistik dan sastera. Pengetahuan tersebut salah satu aspek penentu kepercayaan guru dalam proses pengajaran dan pembelajaran di bilik darjah (Mahat Afifi, 2014). Oleh yang demikian, Andrew (1994) menegaskan bahawa pentingnya seorang guru untuk mempunyai pengetahuan tentang hukum-hukum tatabahasa dan istilah bagi meningkatkan keyakinan dari segi pertuturan serta penulisan.

Justeru itu, kajian juga mendapati kaedah yang digunakan dalam meningkatkan penguasaan pengetahuan isi kandungan pada tahap yang sederhana rendah. Seorang guru pelatih dapat meningkatkan penguasaan isi kandungan tatabahasa Tamil dengan pelbagai cara yang berbeza. Kajian lepas seperti kajian Eric Rui Yuan, (2016) mencadangkan agar guru pelatih meminta bantuan dari guru yang berpengalaman bagi meningkatkan pengetahuan isi kandungan. Hal ini kerana guru berpengalaman boleh dijadikan sebagai mentor kepada guru pelatih supaya dapat membimbing mereka untuk mengukuhkan pengetahuan isi kandungan. Guru pelatih juga boleh merujuk pelbagai buku rujukan bagi meningkatkan pengetahuan isi kandungan mereka seperti yang dicadangkan melalui kajian Rohaida Mazlan (2017). Sanitah Mohd Yusof, Dalila Syazana Zainuddin dan Abdul Rahim Hamdan (2017) turut menyokong bahawa selain buku teks, guru perlu melambakkan rujukan dan ilmu di luar bahan yang disediakan oleh kurikulum agar memberi pengetahuan kandungan yang efektif kepada murid. Natijahnya, warga pendidik diseru untuk melengkapkan diri dengan pengetahuan isi kandungan yang terkini supaya dapat melaksanakan PdP tatabahasa yang efektif

\section{KESIMPULAN}

Secara keseluruhannya, melalui dapatan kajian yang diperoleh, dapat dirumuskan bahawa pengetahuan isi kandungan terhadap tatabahasa Tamil Tingkatan Empat memberi implikasi kepada pelbagai pihak berkepentingan terhadap mata pelajaran Bahasa Tamil. Hasil kajian yang ditemui dapat mengemukakan kepentingan menguasai pengetahuan isi kandungan tatabahasa dalam kalangan guru-guru khususnya guru pelatih dari institusi yang dikaji mahupun bagi guru pelatih dari IPG dan IPTA lain. Kajian ini mampu menimbulkan kesedaran dalam diri guru pelatih bagi menguasai pengetahuan isi kandungan tatabahasa Tamil supaya dapat melaksanakan proses pembelajaran dan pemudahcaraan dengan yakin. Seterusnya, melalui kajian ini guru pelatih dapat mengetahui cara untuk meningkatkan penguasaan pengetahuan isi kandungan mereka dengan efisien.

Kajian ini juga akan dapat menyedarkan guru-guru berpengalaman tentang kepentingan menguasai pengetahuan isi kandungan serta menggalakkan mereka untuk membantu guru pelatih bagi meningkatkan pengetahuan isi kandungan tatabahasa Tamil mereka. Pihak institusi dan Kementerian Pendidikan Malaysia (KPM) dapat mengetahui kepentingan menguasai pengetahuan isi kandungan tatabahasa dalam kalangan guru-guru dan mengambil langkah yang efektif dengan menjalankan bengkel dan kursus latihan khususnya kepada guru-guru pelatih.

\section{RUJUKAN}

Abdul Shatar. (2007). Pengetahuan isi kandungan dan pedagogi guru Pendidikan Moral Tingkatan Empat di sebuah sekolah menengah. (Tesis Doktor Falsafah yang tidak diterbitkan), Universiti Malaya, Kuala Lumpur.

Alderson, J. C., \& Horak, T. (2011). Metalinguistic knowledge of undergraduate students of English language and linguistics. Paper presented at the Subject Centre for Languages Linguistics and Area Studies in Higher Education., Lancaster.

Alderson, J. C., Clapham, C., \& Steel, D. (1997). Metalinguistic knowledge, language aptitude and language proficiency. Language Teaching Research, 1(2), 93-121. 
Alfaro, V., Kupczynski, L., and Mundy, M.-A. (2015). The relationship between teacher knowledge and skills and teacher attitude towards students with disabilities among elementary, middle and high school teachers in rural texas schools. Journal of Instructional Pedagogies, 16, 15-27.

Al-Mekhlafi, A. M., \& Nagaratnam, R. P. (2011). Difficulties in teaching and learning grammar in an EFL context. International Journal of Instruction, 4(2), 69-92.

Andrews, S. (1994). The grammatical knowledge and awareness of Hong Kong teachers of English. In e. a. N. Bird (Ed.), Language and learning proceedings of ILEC 1993 (Vol. 508-520). Hong Kong: Institute of Language in Education, Education Department.

Aslan-Tutak, F., \& Adam. (2015). A Study of Geometry Content Knowledge of Elementary Pre-service Teachers. International Electronic Journal of Elementary Education, 7(3), 301-318.

Ball, D. L., \& McDiarmid, G. W. (1990). The subject-matter preparation of teachers. In W. R. H. a. M. H. J. Sikula (Ed.), Handbook of research on teacher education (pp. 437-449). New York: Macmillan.

Benjamin, A., \& Berger, J. (2013). Teaching grammar : What really works. USA: Routledge.

Bloor, T. (1986). What do language students know about grammar ? . British Journal of Language Teaching Research, 24(3), 157-160.

Borg, S. (2001). Self perception and practice in teaching grammar. ELT journal, 55, 21-29

Cajkler, W., and J. Hislam. (2002). "Trainee Teachers' Grammatical Knowledge: The Tension Between Public Expectation and Individual Competence." Language Awareness 11: 161-177.

Chee, J., Mariani, M. N., Othman, A. J., \& Nor Mashitah, M. R. (2017). Understanding the content pedagogical knowledge among preschool teachers and application of developmentally appropriate practices in teaching. International Journal of Advanced and Applied Sciences. https://doi.org/10.21833/ijaas.2017.03.023.

Cochran, K. F., DeRuiter, J. A., \& King, R. A. (1993). Pedagogical content knowing: An integrative model for teacher preparation. Journal of Teacher Education, 44 (4), 263-272.

Diezmann, C. M., \& Watters, J. J. (2015). The Knowledge Base of Subject Matter Experts in Teaching: A Case Study of a Professional Scientist as a Beginning Teacher. International Journal of Science and Mathematics Education, 13(6): 1517-1537. http://dx.doi.org/10.1007/s10763-014-9561-x.

Donna, J.D \& Hick, S.R,. (2017). Developing Elementary Pre-service Teacher Subject Matter Knowledge Through the Use of Educative Science Curriculum Materials, Journal of Science Teacher Education, 28(1), 92-110.

Eggen, P. \& Kauchak, D. (2007). Educational psychology: Wind.

Eric RuiYuan. (2016). The dark side of mentoring on pre-service language teachers' identity formation. Teaching and Teacher Education, 55: 188-197.

Herold, F \& Waring, M. (2017). Is practical subject matter knowledge still important? Examining the Siedentopian perspective on the role of content knowledge in physical education teacher education. Physical Education and Sport Pedagogy, 22(3), 231-245.

Hlas, A., \& Hildebrandf, S. (2010). Demonstrations of pedagogical content knowledge: Spanish Liberal Arts and Spanish Education majors' writing. L2 Journal, 2(1-22).

Iserbyt, P., P. Ward, and J. Martens. (2015). "The Influence of Content Knowledge on Teaching and Learning in Traditional and Sport Education Contexts: an Exploratory Study." Physical Education and Sport Pedagogy.

Kacani, L., \& Mangelli, S. (2013). Albanian Teachers' Perceptions about difficulties in teaching and learning grammar of EFL. Journal of Educational and Social Research, 3(3), 149-156.

Kacar, I. G., \& Zengin, B. (2013). Perceptions of pre-service teachers of English towards grammar teaching in the Turkish context. The Journal of Language and Linguistic Studies, 8(3), 50-80.

Kementerian Pelajaran Malaysia. (2010). Standard Guru Malaysia. Kuala Kumpur: Kementerian Pelajaran Malaysia.

Kementerian Pendidikan Malaysia. (2014). Jemaah Nazir dan Jaminan Kualiti. Kuala Lumpur: Bahagian Pendidikan Guru, Kementerian Pelajaran Malaysia.

Kementerian Pelajaran Malaysia. (2017). Laporan Kupasan Mutu Jawapan Mata Pelajaran Bahasa Tamil. Kuala Lumpur: Lembaga Peperiksaan Malaysia, Kementerian Pelajaran Malaysia.

Keser, H., Ozcinar, Z., Kanbul, S., Mansor, R., Halim, L., \& Osman, K. (2010). World Conference on Learning, Teaching and Administration PapersTeachers' knowledge that promote students' conceptual understanding. Procedia - Social and Behavioral Sciences, 9, 1835-1839. doi: http://dx.doi.org/10.1016/j.sbspro.2010.12.410.

Krejcie, R.V., \& Morgan, D.W. (1970). Determining Sample Size for Research Activities. Educational and Psychological Measurement, 30, 607-610. 
Lafayette, R. C. (1993). Subject-matter content: What every foreign language teacher needs to know. I. In G. Gunterman (Ed.), Developing language teachers for a changing world (pp.124-150). Lincolnwood, IL: National Textbook Company.

Mahat Afifi. (2014). Pengetahuan pedagogi Hiwar guru Bahasa Arab J-Qaf sekolah rendah. (Tesis sarjana yang tidak diterbitkan), Universiti Kebangsaan Malaysia, Kuala Lumpur.

Manonmani Devi, A. (2015). Tamil Ilakkana Marapum Corpunarcci Vitikalum.(Thesis Doktor Falsafah yang tidak diterbitkan), Madurai Kamaraj Universiti, Tamil Nadu.

Manonmani Devi, A., Ani Omar., \& Veeralaksmi, S. (2017). Penguasaan dan Persepsi Guru Pelatih Terhadap Pembelajaran Tatabahasa Punarcci. Journal of Education and Social Sciences, 7 (1), 141-146.

Manonmani Devi, A., \& Ani Omar. (2019). Keberkesanan Penggunaan Module Pembelajaran Tatabahasa Punarchi. Dlm Eksplorasi dan kreativiti dalam penyelidikan. Perak: Universiti Pendidikan Sultan Idris, 113-130.

Metz. M. (2018). Pedagogical Content Knowledge for Teaching Critical Language Awareness: The Importance of Valuing Student Knowledge, Urban Education, Sage Journals, volume 55 (1),45- 58. doi.org/10.1177/0042085918756714.

Mitton Kukner, J., \& Murray Orr, A. (2015). Inquiring into Pre-Service Content Area Teachers' Development of Literacy Practices and Pedagogical Content Knowledge. Australian Journal of Teacher Education, 40 (5).

Munusamy, S. (2011). Analisis kesilapan penggunaan kasus "Verrumai Urubugal" dalam kalangan pelajar sekolah menengah. (Disertasi Sarjana yang tidak diterbitkan), Universiti Malaya, Kuala Lumpur.

Myhill, D. (2000). Misconceptions and Difficulties in the Acquisition of MetalinguisticKnowledge. Language and Education, 14(3), 151-163. doi: 10.1080/09500780008666787.

Myhill, D., Jones, S., Watson, A., \& Lines, H. (2013). Playful Explicitness with Grammar: A Pedagogy for Writing. Literacy, 47(2), 103-111. http://dx.doi.org/10.1111/j.174 4369.2012.00674.x.

Noor Shah Saad. (2006). Pengetahuan Pedagogi Kandungan dan Amalannya di kalangan guru Matematik sekolah menengah. (Tesis Doktor Falsafah yang tidak diterbitkan), Universiti Pendidikan Sultan Idris, Tanjong Malim, Perak.

Oleg A.S., Kim, I., Ward, P., Curtner, S,M., \& Li, W.Dong., (2016). Changing beginning teachers' content knowledge and its effects on student learning. Physical Education and Sport Pedagogy, 21(4), 425-440.

Rohaida Mazlan. (2017). Tahap pengetahuan, pemahaman dan kesediaan guru bahasa Melayu dalam melaksanakan kajian pengajaran. Jurnal Pendidikan Bahasa Melayu. Malay Language Education Journal, 7(2), 30-40.

Sanitah Mohd Yusof, Dalila Syazana Zainuddin \& Abdul Rahim Hamdan. (2017). Teachers' Experience in Curriculum Implementation: An Investigation on English Language Teaching in Vocational Colleges in Malaysia. Sains Humanika, 4(2), 48-59.

Siping, L. (2013). Pedagogical Content Knowledge: A Case Study of ESL Teacher Educator. English Language Teaching, 6(7), 128-138.

Siti Mistima Maat, \& Effandi Zakaria. (2014). Analyzing Pedagogical Content Knowledge of Algebra using Confirmatory Factor Analysis. Indian Journal of Science and Technology, 7(3), 249-253.

Shing, C. L., Saat, R. M., and Loke, S. H. (2015). The knowledge of teaching-Pedagogical Content Knowledge (PCK). Malaysian Online Journal of Educational Sciences, 3(3): 40-55.

Shulman, L. S. (1986). Those who understand: Knowledge growth in teaching. Educational Researcher, 15(4), 4-14.

Shulman, L. S. (1987). Knowledge and the teaching: Foundation of the new reform. Harvard Educational Review, 57(1), 1-22. doi: http://dx.doi.org/10.17763/haer.57.1.j463w79r56455411

Williamson, J., \& Hardman, F. (1995). Time for refilling the bath? A study of primary student-teachers' grammatical knowledge. Language and Education, 9(2), 23-45.

Xu, W. (2015). Exploring ESL/EFL Teachers' Pedagogical Content Knowledge on Reading Strategy Instruction. English Language Teaching, 8(11), 155-175. 